\title{
Teuto-argentino, teuto-brasileiro, teuto-chileno: identidades em debate
}

\begin{abstract}
ARTHUR B. RAMBO*
Resumo: Durante o século dezenove e no decorrer das primeiras décadas do século vinte, foram implantados projetos de colonização alemã no Brasil, na Argentina e no Chile. Apresentavam-se com semelhanças muito grandes nos três países, tanto nos objetivos, como no modelo de estrutura agrária, como na organização das comunidades rurais. Merece ser destacado neste processo a ocupação de grandes regiões mediante um povoamento maciço de exclusiva etnia alemã. Os imigrantes e seus descendentes das primeiras gerações permaneceram fiéis à língua e à tradição alemã. Na condição, porém, de cidadãos dos respectivos países foram sendo assimilados lentamente na sociedade maior que compunham a nação argentina, brasileira ou chilena. Desta situação ambígua, originou-se, a partir da década de 1930, uma discussão em todos os níveis, em torno da interrogação: Depois de duas, três ou até quatro gerações, o que somos, qual a nossa identidade, ainda somos alemães e em que sentido, até que ponto já somos chilenos, argentinos ou brasileiros? Ou, quem sabe nos resumimos a não sermos mais o que fomos e ainda não sermos aquilo que deveremos ser no futuro? Em outras palavras: o que entende o imigrante alemão no Chile quando se autodenomina de teuto-chileno, o imigrante alemão na Argentina, quando se denomina de teuto-argentino, ou o imigrante alemão no Brasil, quando se denomina teutobrasileiro?
\end{abstract}

Abstract: During the $19^{\text {th }}$ century and the first decades of the $20^{\text {th }}$ century, German colonization projects were implemented in Brazil, Argentina and Chile. These colonization projects were very similar in all three countries in terms of their goals, the model of agrarian structure and the organization of rural communities. This process of colonization was characterized by the massive occupation of large areas exclusively by Germans. The immigrants and their descendents of the first generation remained faithful to the German tradition. However, as citizens of those three countries they were slowly assimilated into the Argentine, Brazilian end Chilean societies. This ambiguous situation gave rise, since 1930, to a discussion at all levels focusing on the issue of identity: after two, three or even four generations, what are we? What is our identity? Are we still Germans? In which sense or to what extent are we already Chileans, Argentines or Brazilian? Or perhaps we are no longer what we used to be and are not yet what we should be in the future? In other words: When the German immigrants in Chile call themselves German-Chileans, when German immigrants in Argentina call themselves German-Argentines and when the German immigrants in Brazil call themselves German-Brazilians, what do they men by that?

* Professor do Programa de Pós-Graduação em História da UNISINOS, São Leopoldo, Brasil.

Estudos Ibero-Americanos. PUCRS, v. XXXI, n. 1, p. 201-222, junho 2005 
Palavras-chave: Identidade étnica e imigração. Identidades em transição. Alemães na Argentina, no Brasil e no Chile.

Key words: Ethnic identity and immigration. Identities in transition. Germans in Argentina, Brazil, and Chile.

\section{Introdução}

A entrada do século XIX vai encontrar o Chile, a Argentina e o Brasil na fase da definição de suas nacionalidades. Uma vez conquistadas as respectivas independências, partiram para a consolidação nacional. Os desafios e as tarefas foram múltiplos e variados. Urgia, em primeiro lugar, definir e implantar um arcabouço jurídico institucional compatível com as características e peculiaridades de cada uma dessas novas nações. Umas levaram mais tempo outras menos. Todas, entretanto, terminaram por encontrar o seu caminho. Umas pagaram um preço mais elevado do que as outras pela consolidação através de embates sangrentos entre as facções contrárias, empenhadas na moldagem do perfil das respectivas nacionalidades. Outras realizaram a tarefa sem maiores traumas. Uma vez alinhavadas e razoavelmente consolidadas as instituições políticoadministrativas, uma série de outras frentes complementares, mas fundamentais, tiveram de ser atacadas.

A maioria das nações recém emancipadas da América Latina lutavam com sérios problemas de fronteiras. Os casos mais flagrantes e que aqui nos interessam mais de perto, foram do Chile, da Argentina e do Brasil. Esse problema relacionava-se com um outro não menos importante: os inúmeros e imensos espaços vazios, ou esparsamente povoados, improdutivos, à margem do sistema produtivo nacional, praticamente à mercê do primeiro que os ocupasse. Aconteceu então que a solução para a questão das fronteiras implicava em colonizá-las sistemática e densamente e canalizar os resultados como mais um fator da consolidação nacional. E não se resumia apenas nos recursos gerados no plano econômico. Os ganhos políticos, sociais e culturais não somavam menos.

Desde logo ficou evidente que esse tipo de desafios não encontrava solução, ou melhor, perspectiva de solução a partir das próprias nações envolvidas ou quem sabe das matrizes das quais se tinham separado. Simplesmente não havia gente para povoar e fazer produtivas as grandes regiões vazias do centro sul do Chile, do pampa argentino, da Patagônia, do Chaco e do médio e Alto Paraná na Argentina e as florestas do centro sul do Brasil. Inútil 
também era recorrer a imigrantes vindos da Espanha ou de Portugal. Além de não haver disponibilidade de colonos suficientes, a tradição espanhola e portuguesa contemplava pouco ou nada a possibilidade de um povoamento fundamentado numa agricultura em médias e pequenas propriedades familiares. Entre os espanhóis e portugueses vindos para a América predominava até então, largamente, a filosofia expressa na declaração de Pizarro: "Eu vim pelo ouro e não para abrir sulcos na terra com o arado".

A solução do problema encontrava-se nos países superpovoados e com tradição agrícola dos países da Europa Central e do Norte. Durante o período colonial Espanha e Portugal vedavam o povoamento de suas colônias na América com a imigração sistemática de colonos procedentes de outros países. Uma vez consumadas as independências, praticamente todas elas foram franqueando seus territórios vazios a emigrantes vindos de outras partes da Europa, uns com mais, outros com menos restrições, uns com mais outros com menos eletividade.

Tanto no Brasil, desde 1824, como no Chile, desde 1852, como na Argentina, desde 1848, os imigrantes alemães ocupavam um lugar de destaque entre outras vertentes como italianos, franceses, ingleses, holandeses, etc. Para evitar uma compreensão equivocada do termo "alemão", "alemães", é preciso esclarecer que o qualificativo "alemão" aplica-se a todos os imigrantes procedentes dos territórios nos quais predominou historicamente a chamada "ordem alemã". Portanto pouco ou nada tem a ver com a vinculação político jurídica dos imigrantes à Alemanha como estado. Aliás no período inicial da emigração para a América, nem sequer existia um Estado Alemão. Coexistiam, isto sim, dúzias de ducados, condados, principados, mais ou menos autônomos, sob a hegemonia ou dos Hohenzollern ou dos Habsburgos. O denominador comum que os fazia alemães era a tradição cultural por todos compartilhada, expressa pela "ordem alemã". Para todos os efeitos práticos, portanto, eram alemães os imigrantes vindos dos territórios da Alemanha atual, da Áustria, Suíça, Alsácia, Lorena, Luxemburgo, da Pomerânia, da Silésia, da Boêmia etc.

Este fato complica até certo ponto estudos específicos sobre imigrantes e seus descendentes, vindos ou de províncias de países que não fazem parte ou não fizeram parte da Alemanha como um estado. Realizar, por exemplo, um estudo da presença de austríacos, suíços, luxemburgueses, silesianos, etc., fica complicado, porque para todos os efeitos práticos de identidade étnica, entraram no Brasil como alemães. Algumas dessas levas de imigrantes são, de alguma forma, identificáveis, como os austríacos de "Treze Tí- 
lias", em Santa Catarina, os teuto-russos de Ponta Grossa e um ou outro grupo menor de pomeranos, silesianos, suíços, os teutorussos de Entre Rios, na Argentina. No estudo geral da sua identidade étnica original, na sua caminhada para a inserção no contexto nacional, nos processos a que foram submetidos e o que resultou em termos étnico-culturais, todos podem ser abrigados sob o guarda-chuva de "alemães", "alemães" no sentido cultural da "ordem alemã".

A questão central que se coloca é resumidamente esta: como se deu o itinerário da inserção desses imigrantes alemães, nas realidades nacionais que os acolheram e qual foi a auto-avaliação feita por eles mesmos como sujeitos dessa história; como é que eles próprios se auto-identificavam e se autodefiniam, na passagem da identidade alemã de origem em busca duma identidade argentina, brasileira ou chilena? Essa temática polarizou em meados da década de 1930 uma grande discussão que se desenrolou em nível relativamente elevado em jornais, revistas, congressos, círculos de conferências, encontros, etc. Tudo girava em torno da grande interrogação: após gerações, vivendo como cidadãos argentinos, brasileiros, chilenos, o que afinal de contas está acontecendo com a nossa identidade alemã? $\mathrm{O}$ que ainda persiste em nós do que fomos, o que somos neste momento e o que serão os nossos filhos, netos e bisnetos? A resposta nos é dada em meio a debates que convergem para uma conclusão geral mais ou menos comum. Os descendentes dos imigrantes alemães situavam-se na época, isto é, na década de 1930, na sua grande maioria, num patamar mais ou menos eqüidistante entre a sua identidade étnica original e a identidade étnica oficialmente estabelecida e aceita como paradigma nacional no Chile, no Brasil ou na Argentina. Essa conclusão fundamentava-se no estudo, na observação da dinâmica antropológico-histórica e etno-histórica, que comanda os processos culturais ou, melhor talvez, aos processos de inserção de realidades étnicas minoritárias em majoritárias ou hegemônicas. Franz Metzler, um grande incentivador desses debates através do seu jornal Deutsches Volksblatt, em pareceria com outros intelectuais da época, teorizou com muita competência esse processo. Num concurso de ensaios realizado em torno do tema "Identidade étnica e comunidade nacional" (Volkstum und Volksgemeinschaft, no original), publicado inicialmente no citado jornal e depois numa publicação avulsa, foram reproduzidos os ensaios considerados melhores e mais significativos. 
Esses ensaios mostram que não há incompatibilidade maior em uma pessoa passar a fazer parte de uma nova comunidade nacional, inclusive de duas, já que se trata de uma passagem e conseqüentemente de uma situação jurídica, legal e formal, convencionada entre partes. Quando se trata da inserção étnicocultural simultânea em duas identidades étnicas diferentes, a questão torna-se muito mais complexa. As leis que regem este processo e a dinâmica que os implementa, são leis e dinâmicas inerentes, em última análise, à própria natureza humana como razão de ser e como ponto de partida das culturas e não por leis, regras e dinâmicas elaboradas e, a posteriori, postas em prática pelo homem com o objetivo de preservar as respectivas culturas e regulamentar o contato com outras. Ao fazer a apresentação dos ensaios selecionados, Metzler desenvolveu o seguinte raciocínio em relação a esse processo:

Basta um olhar para a realidade da colônia, o segmento mais significativo dos teuto-brasileiros do nosso meio. Aí a identidade étnica vive e atua. Mas as outras identidades étnicas deixaram aqui e acolá marcas de diversas formas, favorecidas por tais ou quais circunstâncias. As outras identidades étnicas misturam-se em toda a parte na vida dos colonos de sangue alemão e deitam raízes em seu meio. A comunidade cultural dos colonos encontra a sua maneira de expressar-se ora na forma ou conforme os costumes alemães, ora dos brasileiros. Serve-se ou da língua alemã, ou da brasileira, ou faz das duas uma amálgama. A linha mestra da convivência das identidades étnicas é a mesma nas vilas e nas cidades.

É desta forma que nós teuto-brasileiros vivemos em meio a uma mescla de culturas, sem que a grande maioria de nós se dê conta do fato. Esta mistura apresenta-se de forma muito diversa conforme as circunstâncias em que ela ocorre nas diferentes regiões e nas diversas personalidades. Influenciaram o lugar de moradia, a vizinhança, as relações familiares, as características pessoais, a profissão e os objetivos. O certo é que todo o teuto-brasileiro a que se pode aplicar essa denominação carrega em si, de alguma forma e ao mesmo tempo, nas diversas situações, a identidade étnica alemã e brasileira.

Ao luso-brasileiro instruído ou ao alemão recém imigrado, que olham de fora, esse dualismo, essa dicotomia, essa aparente esquizofrenia existencial, pode facilmente parecer negativo, ou pelo menos indesejável, comparando-o com sua própria cultura e seu estilo de vida pessoal. Entende-se obviamente. Mas a dinâmica inexorável da história não se preocupa com questões de estética ou de estilo. Uma vez consumado o corte entre o "sangue e o chão", sempre será uma 
ruptura com pesadas conseqüências. Rompe com muitas coisas e conduz, no julgamento dos representantes de uma etnicidade una, harmoniosa, coesa, em torno de uma identidade étnica e de uma pátria, à clivagem para com aqueles perante os quais o teutobrasileiro é forçado a aceitar o outro, no momento em que suas manifestações culturais não têm mais vez, no contexto de uma etnicidade una, harmoniosamente coesa em torno de uma identidade étnica e de uma pátria. Ele pode conceber a duplicidade de uma situação como uma tarefa exeqüível sob certas condições. Uma tarefa que brotou da história de sua vida ou da história de seus antepassados como conseqüência ou como herança. Ele é de todo compreensível e inteligível no contexto de uma vida honrada e rica. Mesmo que a sua posição ofereça, não raro, de um lado maior vulnerabilidade, de outro, porém, faculta-lhe a percepção e o julgamento livre para duas dimensões e amplia a perspectiva em relação ao homem.

A pergunta é se o homem é capaz de pertencer na mesma medida a uma outra identidade étnica? No longo prazo, não. Como tempo uma das forças terminará sobrepondo-se. Um caso em que esta pergunta poderá ficar sem respostas, é a mesma em que também a dinâmica da evolução de uma história de vida permanece sem resposta. Acontece no caso em que alguém se transfere de uma cultura para a outra, no momento em que cruza a fronteira e transpõe o divisor de sua vida. Um período de passagem dessa natureza em casos isolados, vistos por observador superficial, as relações para cada um dos dois lados parecem as mesmas. Quem está em condições de avaliá-lo? Quem o fizer provavelmente nunca as perceberá como iguais.

Na verdade, o que acontece nos casos de inserção equilibrada em duas identidades étnicas, uma delas será mais superficial e a outra mais profundamente enraizada na personalidade dos indivíduos. Em quase todos os casos, o que decide pela vida em fora são as impressões, as influências e as vivências da juventude, mais do que as percepções étnicas. A grande maioria dos teuto-brasileiros procede de famílias que inseriram os filhos num mundo onde predominavam ainda a língua e os hábitos alemães, sem tomar em consideração a sua herança de sangue. $O$ teuto-brasileiro de que falamos, ostenta por isso, o perfil predominante da vida cultural alemã. Essa realidade torna-se visível ainda hoje em muitos casos em que a língua e a maneira externa de ser apontam para uma completa absorção numa outra identidade étnica. Nesses casos, porém, as tendências profundamente enraizadas no sangue não miscigenado, fazem constantemente valer os seus direitos. 
Os caminhos da comunidade nacional brasileira em busca de uma comunidade cultural, em busca da identidade étnica brasileira integrada, perde-se no horizonte para o observador de hoje. O espaço de tempo alonga-se para uma época em que o País estiver plenamente ocupado e já não aceitar mais imigrantes. Depois disso, será necessário ainda um longo espaço de tempo durante o qual as águas do lago em repouso clareiem. E por quanto tempo a identidade étnica alemã ainda tem condições de viver aqui, de fazer-se valer, até se miscigenar? Dependerá do tempo em que continuarem a existir lares alemães e a desembarcar imigrantes em nossos portos. A partir do momento em que esses pressupostos não estiverem mais presentes, provavelmente algumas gerações ainda se passarão, até o último teuto-brasileiro baixar à sepultura. Seu papel estará cumprido segundo as leis eternas que o Criador colocou na base de suas obras.

Qualquer um que tem um mínimo de conhecimento da dinâmica cultural, no essencial ao menos concorda com Metzler. $\mathrm{O}$ encontro e a convivência mais prolongada de duas ou mais tradições culturais, de duas ou mais identidades étnicas, de dois ou mais Volkstümer, terminam num processo de mútua aceitação, de uma recíproca troca de traços culturais e, finalmente, numa amálgama que justifica falar-se numa nova identidade étnica. Dependendo das circunstâncias, o processo requererá mais ou menos tempo, experimentará mais ou menos turbulências. Em todo caso, na melhor das hipóteses, não se resolve em uma ou duas gerações apenas. Em linha muito gerais, porém, é possível distinguir três fases nessa dinâmica. Na primeira, continua prevalecendo o perfil original da respectiva identidade. A língua fica mantida como veículo de comunicação, os valores, os hábitos, os costumes, as convicções, a herança de sangue, etc., são preservados. Obviamente as circunstanciais sócio-culturais do novo meio e até as características de natureza físico-ambiental, vão ocupando um espaço cada vez maior. Um exemplo característico foi a aceitação e a incorporação do hábito de tomar chimarrão, na rotina do dia a dia dos imigrantes alemães no sul do Brasil.

Numa segunda fase, a inserção da identidade vinda de fora, no presente caso dos descendentes dos imigrantes alemães no Brasil, Chile e Argentina, e em outras partes do mundo, alcançou, por assim dizer, um ponto de equilíbrio, um meio termo. Com as devidas ressalvas, pode-se dizer que se chegou a uma situação étnica esquizofrênica, ou próxima a ela. Fica difícil definir com quem se está falando. No caso concreto dos descendentes de alemães, de um lado, continuando a falar seus dialetos, praticando muitos de 
seus hábitos tradicionais, cultivando os valores que seus ancestrais trouxeram da Europa. Do outro lado, são cidadãos chilenos, argentinos ou brasileiros. Na sua maioria já aprenderam e falam a língua oficial dos respectivos países, cultivam valores e vivem e agem, sob muitos aspectos, como chilenos, argentinos ou brasileiros. Já não aceitam serem chamados de alemães e sim teuto-argentinos, teuto-brasileiros, teuto-chilenos ou algo equivalente. É exatamente essa a situação que mais acima arriscamos chamar de esquizofrenia étnica e que mereceu, nas décadas de 1920 e 1930, a atenção dos descendentes dos imigrantes em geral e dos intelectuais em particular, nos países acima apontados. A pergunta crucial que se formulava era esta: "Como é que os "alemães" se viam a si mesmos, com se identificavam a si mesmos e, de outra parte, como eram vistos e avaliados pelos hispano-chilenos, os hispanoargentinos e os luso-brasileiros ao nível do quotidiano e ao nível dos intelectuais?"

Na terceira fase, e somente para deixar o esquema completo, os descendentes dos imigrantes completaram a sua inserção, ao menos no que se refere aos elementos essenciais, no novo contexto étnico cultural. Agem como qualquer outro chileno, argentino ou brasileiro. Falam espanhol ou português, adotaram o estilo de vida comum a todos. O sobrenome e alguns traços do comportamento apontam ainda para a sua origem remota. No mais, são cidadãos chilenos, argentinos ou brasileiros de sobrenome alemão e nada mais.

O que realmente interessa aqui é a segunda fase. Em torno de suas características e em torno de sua importância se deram as discussões no período de entre-guerras-mundiais. A grande interrogação que pairava no ar era esta: "O que entendem os descendentes dos imigrantes alemães ao se autodefinirem como teutochilenos, teuto-argentinos, teuto-brasileiros?" De outra parte, como é que os hispano-chilenos, os hispano-argentinos ou os lusobrasileiros avaliavam e lidavam com seus concidadãos teutos? Dos debates a nível teórico havidos a respeito na década de 1930, é lícito concluir que: o teuto-brasileiro, o teuto-argentino e o teutochileno é o descendente de alemães, nascido em algum desses países. Como tal é cidadão brasileiro, argentino ou chileno, sujeito a todas as conseqüências práticas desta situação jurídica, mas, ao mesmo tempo, continua fiel, no essencial ao menos, à sua língua e herança cultural. Formulada teoricamente, é esta a definição para a situação em causa. Na prática, porém, no quotidiano, tanto da parte dos teutos, quanto do lado de seus concidadãos de outras procedências, a questão não é tão clara e tão simples assim. 
Uma corrente definiu a situação como sendo simplesmente um fenômeno de transição, um momento de passagem. As pessoas envolvidas não passam de "traços de união", de "hífens". Os autores que escreveram em alemão sobre o assunto costumam usar o termo Bindestrich para "traço de união" hífen, e para a pessoa envolvida no processo de Bindestrichler. Parece que foi este o ponto de vista a nível de intelectualidade teuto-chilena na década de 1930. Para comprová-lo, vale a pena reproduzir um ensaio de autoria do teuto-chileno Christopf Martin sob o título original "Gedanken für das Deutschtum in Chile" - "Reflexões sobre a germanidade no Chile" -, publicado no jornal Deutsches Volksblatt, em Porto Alegre, em 1935.

\section{Reflexões sobre a germanidade no Chile}

Denominam-se teuto-chilenos os descendentes de alemães nascidos no Chile. Trata-se, portanto, de germano-chilenos com cidadania chilena, conseqüentemente chilenos como manda a constituição. Formam um Volkstamm num outro país (Land). Para eles, os conceitos de "povo" e "país" já não coincidem, como coincidiam na terra dos antepassados entre o Maas e o Memel, entre o Etsch e o Belt.

Pergunta-se: por acaso esses conceitos coincidem quando se fala dos outros chilenos? Não, tão pouco. Vale somente para os Mapuches. A grande massa de chilenos, descendentes dos imigrantes vindos da Península Ibérica, formam também um povo num outro país, mesmo que não o saibam ou não queiram admiti-lo.

Pelo direito natural, este país (Land) pertence aos Mapuches, autóctones e autênticos pela raiz (Wurzelechte). Tanto os ibero-chilenos como os germanos ou teuto-chilenos os marginalizaram há pouco tempo, os primeiros há 400 anos e os outros há menos de 100 anos. O povoamento da terra dos Mapuches garantiu, sobre ela, direitos iguais aos iberos e germanos, mas nenhum deles pode ser considerado "autênctico pela raiz" (Wurzelecht). É verdade, deitaram aí raízes permanentes e esta terra tornou-se a sua pátria. $O$ direito sobre o Chile dos imigrantes ibéricos e dos imigrantes germanos distingue-se apenas pelo fato de os primeiros somarem dez vezes mais habitantes do que os segundos e porque chegaram alguns séculos antes.

O mesmo é válido para os imigrantes procedentes de outros países (Itália, Inglaterra, Turquia, etc.). Não fazem parte das considerações que seguem.

Os ibero-chilenos organizaram o país de acordo com seus hábitos e determinaram a Constituição e a língua. "País e povo não coincidem para eles e sim 'Estado e povo'." Os teuto-chilenos foram obrigados a conformar-se com essa realidade, o modelo estava posto. Não tinham condições de tentar algum tipo de mudança, uma vez que contavam com nú- 
mero muito reduzido. Adaptaram-se, por isso, à forma já existente de Estado e transformaram-se nos melhores cidadãos do país. Raras vezes sua presença podia ser notada fora dos limites em que se encontravam, no seu próprio meio e poucas vezes em postos mais elevados da administração das cidades. Agarravam-se decididamente aos costumes e à língua que tinham trazido. Fundaram associações para suprir as exigências que o estado chileno não tinha condições de oferecer (escolas alemãs, igreja, arte, esporte e sociabilidade) e instituíram contribuições espontâneas de valores extraordinários. O Estado não se intromete, pois cumprem as leis e vivem na mais perfeita harmonia com os cidadãos de outras procedências.

Pois bem. Em que terminaram? Naquilo que vemos hoje. "Traços de união" - Bindestrichler. Apesar de toda a estima e todo o apreço que o Estado Chileno Ihes devota, o ibero-chileno, em última análise, não o considera como cidadão pleno. No fundo, apenas ele próprio, o ibérico, considera-se um autêntico chileno. "O traço de união" - o Bindestrichler, também não é considerado "pleno" pelos alemães recém imigrados (Neudeutsche), porque não são capazes de entender a disposição de pertencer ao Estado Chileno e as conseqüências que daí decorrem. Para entendê-lo é preciso viver na prática a situação em que os conceitos de Povo e Estado não coincidem.

O germano-chileno que reflete sobre si mesmo tem consciência da sua situação. Sente-se como cidadão chileno e como tal cumpre as suas obrigações. Sua posição em relação ao Estado é absolutamente clara. A sua relação espiritual para com os ibéricos e os "alemães novos" (do Reich), isto é, os alemães que tiveram a sua formação cultural na Alemanha (em qualquer um dos estados da Alemanha) e só depois vieram para cá, fica mais difícil de precisar.

Justamente nos últimos tempos foram levantadas questões controvertidas por pessoas que há apenas pouco tempo vêm-se ocupando com esse tipo de problemas. Redescobriu-se que teuto-chilenos e alemães do Reich não são bem a mesma coisa. Na verdade a diferença não consiste no fato de uns falarem o alemão os outros o espanhol pior do que os demais. Existe uma diferença de caráter não detectável, um algo que nos distancia. Embora se invoquem muitos fatores que teriam contribuído para acontecer uma evolução não coincidente (menciona-se o clima, a alimentação, menor capacidade de competição, maiores oportunidades, ganho mais fácil de dinheiro, menor resistência ao ambiente e coisas que tais). Pessoalmente considero uma outra influência mais importante e responsável pela formação de caracteres diferentes em elementos da mesma raça e da mesma matriz genética. Dela quero falar agora.

$\mathrm{Na}$ Alemanha senhor e criados pertencem à mesma estirpe, assim como os comerciantes, artesãos, colonos e soldados. A vida acontece num clima de maior confiança e em meio a uma maior simplicidade. A babá fala a língua dos senhores e cultiva a mesma concepção em relação ao mundo que os rodeia. As pessoas se conhecem e se entendem. 
Terra, Povo e Estado coincidem. Aqui no Chile, pelo contrário, a babá é uma autóctone. As pessoas desde os dois anos vivem em dois mundos. De um lado, a casa paterna alemã, escola, igreja, associações alemãs. Do outro lado, criadagem mapuche, escolas superiores, serviço militar, universidade, amizades, ibero-chilenos. Essa realidade faz com que a vida toda se desenrole numa duplicidade, que se requer das pessoas que queiram localizar-se na situação, uma forma dupla de pensar. Obviamente o caráter é afetado a tal ponto que o recém imigrado só após anos é capaz de compreender. O mundo-ambiente em que vive faz o teutochileno mais calculista e mais cauteloso na sua maneira de falar e agir. Costuma ser condescendente em relação aos inferiores, aos nativos. Procura acentuar as diferenças pela aparência externa. Sente-se como senhor. Em relação aos ibéricos da mesma posição costuma ser polido, escolhe as palavras e guarda não poucos pensamentos sem expressálos. Ao conversar, tanto uns como os outros apreciam a pose. Não nos apresentamos como somos mas como gostaríamos que fôssemos. Esta maneira de nos relacionarmos mutuamente exige esforço com o correr do tempo. Requer um permanente câmbio na maneira de ser, com os iberochilenos de um lado e com os alemães do Reich, do outro.

Os germanos transplantados mantêm uma característica em comum quaisquer que sejam as circunstâncias ambientais em que vivem, quer se trate da vistosa capital, quer se trate dos "fundos" cultivados pelos índios maputches. O ambiente inteiramente estranho força a tomálo a sério para de alguma forma conviver com ele.

No momento em que um alemão recém chegado entra pela primeira vez em contato com o teuto-chileno, certamente não faz idéia com que alegre disposição é recebido, ele e tudo que dele se espera. $O$ teutochileno tem consciência que sem o fluxo constante da cultura alemã pura de lá para cá, a germanidade com o tempo não se sustentará. Precisamos de renovação. Temos ocasião de ouvir então a língua alemã sem a intromissão do espanhol.

O teuto-chileno é, sem dúvida, muito sensível às críticas e aos resmungos dos recém-chegados. Irrita-se com as observações negativas sobre o Chile e ofende-se quando ridicularizam as instalações conquistadas com tanto esforço pelos teuto-chilenos e quando se fazem comparações exageradas com instalações alemãs do Reich. $O$ teuto-chileno se fecha. Ele quer aprender do outro, aceita com boa vontade conselhos, mas não quer ser visto como alguém de segunda categoria.

Seria tão bom que os alemães do Reich se dessem conta disso ao aqui chegarem! Com muita probabilidade, muitos desentendimentos relacionados com os julgamentos divergentes de valores entre alemães antigos e novos, cessariam de vez.

Como é que os descendentes dos germanos transplantados lidam com o contexto em vivem? 
Uns se adaptam inteiramente a esse meio. São por ele absorvidos, "achilenizaram-se" como se afirma equivocadamente. O termo certo seria "hispanizaram-se". Da sua origem fica apenas o sobrenome alemão, muitas vezes grafado de forma errônea. Sua alma irrequieta encontrou a paz, mas perderam a identidade alemã.

Os outros evitam o conflito, na medida em que se isolam como estrangeiros descontentes no país, lendo somente livros e jornais do Reich. Comparam a Alemanha com o Chile em detrimento do segundo. Procuram não se interessar pelas questões do país em que vivem, e alimentam durante a vida toda a nostalgia pela Alemanha que está fora do seu alcance. Quem hoje tem condições de viajar para a Alemanha considerando o valor do dinheiro chileno e a uma distância tão grande? Passam a vida entediados e só pela metade e se recusam a pensar que esta terra, que eles não reconhecem como pátria, deverá ser a pátria de seus filhos.

Os terceiros, os "traços de união", os Bindestrichler batalham a vida inteira contra o mundo que os rodeia, batalham em busca do equilíbrio interior. Têm consciência de sua procedência e enquanto se sentem como cidadãos plenos do Estado Chileno, cultivam, ao mesmo tempo, as peculiaridades de ser de sua origem, em particular a cultura, a língua e os costumes. Assumem-se como teuto-chilenos, afastam a nostalgia pela terra inacessível da sua procedência e em vez dela amam este chão com suas extraordinárias belezas. Permanecem fiéis à germanidade. Agarram-se a ela com maior persistência do que muito recém-imigrado sem convicções e educam as gerações nesta direção. Conquistam penosamente a sua posição, evidentemente pagando o preço da tranqüilidade de sua alma, pois sua alma batalha para firmar-se entre os conceitos de "Povo" e "Estado". Pendulam sobre o "traços de união". Nisto consiste a grande tragédia dos representantes transplantados das outras raças, para quem Povo e Estado são realidades distintas. Os recém imigrados não entendem essa tragédia. Ainda não tiveram tempo para percebê-la e consideram os envolvidos nela como de menos valia e os avaliam através de elementos externos. O "elo de união" revolta-se contra esse desprezo para ele incompreensível. O alemão do Reich não entende a situação difícil, que requer uma cautela infinitamente grande da parte do "traço de união" em relação ao Estado Chileno e aos ibero-chilenos. Julga o tatear cauteloso como uma atitude não alemã. Apenas é possível vislumbrar o tamanho da importância para a germanidade no momento em que os cidadãos teuto-chilenos, conscientes de sua origem, conquistarem influência na vida pública.

O breve ensaio de Christopf Martin que acabamos de reproduzir, defende um ponto de vista inequívoco sobre os teutochilenos. Para ele, o teuto chileno não passa de um "traço de união", um Bindestrichler entre a realidade de onde vieram os imigrantes alemães no Chile e a sua tentativa de inserção na realidade nacional chilena. Como tais, eles se situam entre duas realidades, 
representam um fenômeno sociocultural e político de transição, um "hífen", na verdade, sem uma identidade definível. As circunstâncias sociais, políticas, econômicas, culturais e até mesmo as geográfico-ambientais, o fato de juridicamente pertencer ao Estado Chileno, fizeram que deixassem definitivamente de serem alemães no sentido dos alemães do Reich. Conservando, porém, os elementos essenciais da cultua alemã: a língua, os costumes, os hábitos, os valores, ainda não podem ser considerados chilenos plenos. Por isso mesmo são vistos no mínimo com reserva ou até com indisfarçada desconfiança pelos ibero-chilenos. De outra parte, os alemães do Reich olham para eles com uma ponta de comiseração e até com aberto desprezo, devido à sua "decadência cultural". O próprio autor do ensaio os classifica como "criaturas dignas de pena", que deixaram de ser o que foram e ainda não são o que deverão ser. Em outras palavras. Carecem de identidade e sob este aspecto não são ninguém.

\section{Reflexões sobre o teuto-brasileiro, o teuto-brasileirismo}

A seguir quero reproduzir uma parte de um outro ensaio sobre a mesma temática, desta vez relativo aos descendentes de imigrantes alemães no sul do Brasil. O autor, Franz Metzler, ao referir-se aos teuto-brasileiros, defende uma posição, não contrária, mas visivelmente discordante daquela de Christopf Martin em relação aos teuto-chilenos. Para Metzler, o teuto-brasileiro também representa uma realidade em "transição". A diferença, porém, consiste no fato de o teuto-brasileiro ser entendido como uma realidade definível, uma realidade passível de identidade própria, num determinado momento da sua inserção no contexto nacional brasileiro. Não é uma figura "digna de pena" que pendula hesitante entre a identidade que está em vias de perder e a nova que vem adquirindo. Para Metzler, há um momento, uma fase no processo, com a duração de uma ou mais gerações, em que a transição assume as características de uma identidade transitória, é verdade, mas ostentando um perfil que lhe confere consistência e existência própria e inconfundível, em meio ao contexto sócio cultural em que se encontra. $\mathrm{O}$ teuto-brasileiro, o teuto-brasileirismo, foi uma realidade que marcou amplamente o cenário do sul do Brasil no final do século XIX e nas primeiras décadas do século XX. Continua presente de alguma forma em bolsões isolados no Rio Grande do Sul, Santa Catarina e Paraná. Representam-nos aqueles brasileiros que no quotidiano continuam vivendo de acordo com as tradi- 
ções dos antepassados alemães, falando os dialetos, praticando os costumes e os hábitos e cultivando os valores herdados dos antepassados. Quanto à identidade étnica, portanto, são "alemães" ou teutos. Mas pelo fato de terem nascido no Brasil, pelo princípio do ius soli, são cidadãos brasileiros, incluindo tudo que essa situação legal implica em termos de direitos e deveres. Quanto à identidade civil, portanto, são brasileiros. As duas dimensões amalgamam-se numa identidade: o teutobrasileiro. Por essa razão, e para evitar mal entendidos, Metzler escreve teutobrasileiro, sem a separação por hífen. Para eles próprios não há nenhuma contradição nesta situação, muito menos características de esquizofrenia existencial. Historicamente estiveram habituados a distinguir na prática a sua identidade étnica, do eventual pertencimento a um determinado Estado. Não há necessidade de insistir que do lado luso-brasileiro, ibero-chileno ou ibero-argentino, houvesse dificuldades maiores, pois essas tradições tinham como base da identidade a nacionalidade e a cidadania como fatos coincidentes e indissociáveis. Esses posicionamentos históricos divergentes, foram, sem dúvida, em grande parte responsáveis pelos desencontros havidos entre teutobrasileiros e luso-brasileiros, na década de 1930 e 1940. Sua análise mais aprofundada extrapola as pretensões deste artigo. Passemos a uma das matérias publicadas no Deutsches Volksblatt em que Franz Metzler detalha o seu conceito de teutobrasileiro:

Os caminhos da comunidade nacional brasileira em busca de uma comunidade cultural, em busca da identidade étnica brasileira integrada, perde-se no horizonte para o observador de hoje. O espaço de tempo alonga-se para uma época em que o País estiver plenamente ocupado e já não aceitar mais imigrantes. Depois disso, será necessário ainda um longo espaço de tempo durante o qual as águas do lago em repouso clareiem. E por quanto tempo a identidade étnica alemã tem condições de viver aqui, de fazer-se valer, até se miscigenar? Dependerá do tempo em que continuarem a existir lares alemães e a desembarcar imigrantes em nossos portos. A partir do momento em que esses pressupostos não estiverem mais presentes, provavelmente algumas gerações ainda se passarão, até o último teutobrasileiro baixar à sepultura. Seu papel estará então cumprido, segundo as leis eternas que o Criador colocou na base de suas obras.

O teutobrasileirsmo significa um fenômeno de transição histórica. A humanidade resume-se numa história de transições. Nós teutobrasileiros, com a nossa maneira de ser e pensar, fazemos parte da História. Somos uma realidade feita história. Há pouco tempo, em Porto Alegre, um eminente alemão do Reich afirmou em certa ocasião: "Não conheço teutobrasileiros; ou o respectivo é alemão ou é brasileiro; teutobrasileiro é um contra-senso". Nós da nossa parte conhecemos teutobrasileiros como 
sujeitos históricos reais. Temos aqui um exemplo ilustrativo que comprova a suspeita expressa mais acima, que o teutobrasileiro em algumas situações tem uma visão mais abrangente sobre os homens e as coisas, de modo especial quando os homens e as coisas se encontram no Brasil.

No uso quotidiano o conceito "teutobrasileiro" não está definido. Aqui requer-se, porém, uma definição bem precisa. Em vista das considerações que seguem, a quem eu definiria como teutobrasileiro? Toda e qualquer pessoa nascida em território brasileiro ou naturalizado que, consciente e declaradamente pretende, no futuro, ter este País como pátria. O segmento decisivo que representa o teutobrasileirismo e a que se destina essa pergunta, enquadra-se nesta definição.

O acento deve cair sobre a segunda parte do termo "teutobrasileiro", pois a nossa vida concreta como cidadãos desenrola-se neste cenário. Nele fundamentam-se os direitos e os deveres para com a pátria. Fundamentam-se também as mais profundas vivências étnicas relacionadas com a pátria e com a querência natal.

Temos credenciais para alto e bom som nos chamarmos brasileiros. Quem quereria e quem estaria autorizado a nos negar este título? Entre eles incluímos aqueles que, algum dia, sem a mínima preocupação, deixaram partir os nossos antepassados. Incluímos também os que recentemente nos redescobriram. Mas deixemos as coisas como estão porque a nossa ambigüidade procede de uma dinâmica compreensível e lógica. Em primeiro lugar trata-se de uma característica natural de um país que está sendo colonizado por tantas vertentes étnicas. Em segundo, lugar impõe-se uma declaração intencional de adesão à nossa maneira de ser. Se o lusobrasileiro se autodenomina assim baseado nos mesmos motivos, porque nós iríamos passar em silêncio a nossa condição de teutobrasileiros? A essa altura acresce para nós mais uma razão. Sob essa denominação assumimos o compromisso de perpetuar uma tradição: "em memória dos nossos antepassados".

Para aqueles que nos rotularam de "hífen", de "traço de união", temos como resposta que escrevemos as duas palavras, uma ao lado da outra, sem traço de união, sem hífen. Temos os mesmos anseios dos nossos antepassados, isto é, irmanar, íntima e sinceramente, o amor à pátria e a fidelidade à nossa maneira de ser alemã. No caso de, apesar disso, continuarem a nos estigmatizar como "traços de união", que se dêem ao trabalho de circular pelos lugares onde se trabalha no Brasil (que, aliás, costumam ser pouco conhecidos para essas pessoas), e tentem avaliar o quanto ser um "traço de união" é capaz de realizar quando apoiado em fundamento alemão. Depois de concluírem um balanço sem preconceitos, aceitamos sem problema que nos rotulem com dois "hífens" - honoris causa.

Está na hora de nós teutobrasileiros avaliarmos e de nos mostrarmos em outras ocasiões um pouco mais cônscios de nós mesmos. Temos sido até agora exageradamente discretos, para afirmarmos as duas dimensões tanto a alemã como a brasileira. As razões são óbvias. Falta- 
nos a orientação e a conscientização. Nos casos em que, entre nós, a versatilidade e o potencial do espírito foi desestimulado pela formação e pelas nossas capacidades, evidenciou-se, não raro, um rápido desinteresse da nossa parte. Sofremos da passividade, o que nos prejudica na vida pública e no relacionamento social. A média do nosso nível cultural (esperemos que assim continue ainda por muito tempo) é a do agricultor. Entende-se assim a nossa discrição e o hábito de ficar na retaguarda. Nos últimos anos, entretanto, presenciamos, por exemplo, da parte dos alemães recém-chegados ao País, de forma ostensiva, a reivindicação de, em nome da filiação a um partido político do Reich assumir a condução da germanidade. Tentaram fazer valer as suas pretensões, ignorando onde possível, as nossas associações culturais e o cultivo da germanidade aqui. Neste caso caberia a nós que temos a nossa base numa comunidade essencialmente rural, contrapor a necessária resistência a essas tentativas (elas obtiveram em muitos lugares um êxito apreciável e profundo), com a resposta concreta: "Em memória dos nossos antepassados".

O teutobrasileirismo não se posiciona com a suficiente determinação (excetuando as iniciativas não devidamente valorizadas de algumas pessoas isoladas). Na maioria dos casos mostra-se muito passivo e muito desinteressado em relação aos assuntos que lhe dizem respeito. Com freqüência a bondade natural e a comodidade representam um obstáculo para assumir o comando de seus interesses. Este fato deveria servir-nos de lição e fazer com que, sem tardar, tomemos certas conclusões em relação ao futuro.

A germanidade daqui formava antigamente uma grande comunidade de coração aberto e com isso se dava bem. Também o lusobrasileirismo se posicionava e se posiciona ainda hoje de coração aberto em relação a nós. Foi pequena a consciência de nossas necessidades e as conseqüências daí decorrentes.

Uma coisa é certa. O valor do cultivo da nossa identidade étnica reside na sua espontaneidade. A fidelidade e o empenho que nós, nós que há gerações nos encontramos no País, oferecemos, constitui-se antes de mais nada, numa dádiva livre. Nós teutobrasileiros permanecemos fiéis à nossa identidade étnica de origem, espontânea e livremente. Assim será sempre! O que mais se pode esperar de nós? Cultivamos essa maneira de ser como algo óbvio da nossa identidade, da mesma maneira como os elementos de sangue alemão em outros países. Entre nós prevaleceu um estilo de relacionamento ao mesmo tempo civilizado e espontâneo como convém à maneira de ser do País. Esta comunidade étnica sofre hoje perturbações sérias. Observamos que uma minoria insignificante de alemães do Reich tenta impor-se neste meio, com pretensões de serem mestres e líderes a um nível até agora desconhecido para nós. Os alemães levados por interesses político partidários, façam o que quiserem no âmbito de seus círculos. Nós teutobrasileiros rejeitamos com muitas e sólidas razões e com toda a veemência a sua liderança em nossas asso- 
ciações culturais. Não somos alemães que se encontram aqui de passagem. Residimos aqui e somos cidadãos deste País. É nessas condições que cultivamos as nossas características étnicas aqui, neste País, mais sensível para com nossa vida cultural teutobrasileira. Aconteceu a clivagem da nossa antiga comunidade. Essa lamentável evolução, profundamente prejudicial ao nosso convívio étnico, está claramente visível e tornou-se objeto de reflexões entre teutobrasileiros e alemães do Reich.

Deste contexto emerge o risco de não poucos de nós, e não os piores, se distanciarem dos círculos em que a nossa identidade étnica é cultivada e na medida em que a questão se arrasta mais e mais, declarem: "Diabos! O que importa tudo isso? De qualquer forma não resultarão vantagens para a germanidade"

Mais uma conseqüência. Em nossas organizações de natureza étnica, nós teuto-brasileiros, na condição de maioria predominante, exerceremos cada vez mais representatividade e ocuparemos a dianteira. Há muitos anos os alemães do Reich vêm prestando os melhores serviços a sociedades e muitos deles tornaram-se líderes. Trata-se de homens que se sentiam em casa entre nós. Conheciam a terra, a gente, a nossa maneira de ser e as nossas necessidades. De uma maneira ou outra, sobressaíam pelo seu valor pessoal. Exerciam a sua influência de uma forma por nós conhecida, sem que a percebêssemos como algo estranho. Nunca nos disseram que nos engajássemos num trabalho conjunto em favor da identidade étnica. Há pouco tempo houve a tentativa de "ensinar", com tais ou quais métodos coercitivos, coisas totalmente estranhas entre nós, como por exemplo, adotar em nossa germanidade uma postura afinada com modelos alemães. A iniciativa partiu de pessoas não credenciadas para tanto, nem pela participação na construção da nova Alemanha nem pelas suas realizações no Brasil. O motivo alegado para exercerem a liderança explicava-se pela sua filiação a um partido político alemão.

Trata-se de algo absolutamente novo em nossa história teuto-brasileira e totalmente inaceitável para nós teuto-brasileiros. Nessa questão esconde-se uma grande ameaça ao nosso bom e correto relacionamento com os lusobrasileiros. Os nossos interesses políticos para com a comunidade nacional são de qualquer forma determinantes. Líderes abandonam com facilidade o país que os hospeda no momento em que se torna necessário ou oportuno e deixam para nós o que sobra. A conclusão é óbvia. Teuto-brasileiro trata de assumir melhor a tua causa! Não dispensa os alemães do Reich que se mostraram líderes e colaboradores confiáveis e vai em busca de outros, também dentre as suas fileiras. É preciso que sejam homens engajados no compromisso com a germanidade e não com a vida partidária alemã.

Além disso segue como conseqüência da nossa posição ambivalente que procuremos concretizar uma relação política e econômica, a melhor possível, entre os dois países, representados por cada teutobrasileiro por força de sua autodeterminação. E quanto mais profundas forem as nossas 
raízes aqui e quanto mais sólida a nossa cidadania, quanto maior for a nossa influência na comunidade nacional brasileira, tanto mais condições teremos para concretizar esse objetivo. Por essa razão explica-se também o nosso desejo que as importantes organizações para o estrangeiro na Alemanha mostrem ao povo alemão quem e o que somos nós teutobrasileiros. Pois em largos círculos do público alemão, fomos, por muito tempo, considerados apátridas, mais menos dignos de pena.

Mais uma conclusão pode ser tirada das nossas reflexões. Que da nossa parte façamos que nossos filhos entendam tudo o que é grande e o que é belo na Alemanha e na sua história, na medida em que isto é possível aqui. De modo especial cabe-nos tomar como modelo o enorme valor que deposita na educação política de sua juventude. Exatamente por causa da nossa situação ambivalente e por isso mesmo ela pede renovadas explicações, deveríamos esclarecer em detalhes a nossa juventude em formação nas nossas escolas, o direito sagrado que assiste a cada Estado, o de a pátria reclamar inteira dedicação de seus cidadãos. No Brasil aconteceu até aqui a mesma coisa. O termo "totalidade" hoje em moda, pode induzir-nos a dar uma ênfase um pouco maior para 0 nosso dever de patriotas.

Mantemo-nos fiéis à nossa identidade étnica e ao mesmo tempo colaboramos na construção da nova. Não há outra saída. Na prática isso fica mais claro pelas determinações legais do País que tratam da educação da juventude. É indiscutível que hoje o povo alemão (de modo especial a juventude) vive um novo ideal étnico, o "nórdico". É um fato, mesmo que não seja obrigatório por lei. Essa orientação predominante em largos círculos do povo (especialmente na juventude em formação) assume proporções passionais e ao mesmo tempo resultou numa postura de contestação e de rejeição dos valores éticos básicos da vida cultural alemã do passado, a tal ponto que originou uma situação peculiar para nós teutobrasileiros. Pela primeira vez na história defrontamo-nos com a dúvida de haver a possibilidade de manter o paralelismo havido até agora, entre os objetivos étnicos de lá e de cá, caso se prolonguem os acontecimentos na Alemanha. À Alemanha assiste o direito de fazer e deixar de fazer o que lhe aprouver no âmbito de suas fronteiras políticas. Nós da nossa parte estamos por inteiro, cultural e espiritualmente, ligados a ela. Os laços que nos unem são profundos. Os abalos íntimos também nós os sentimos. Acontece que há gerações que fomos jogados nas costas das terras do sul. As leis que regem as características físico-geográficas excluem a nossa participação no culto, nos mitos e no etos específico que tem como paradigma a identidade étnica "nórdica". Exclui a participação com aqueles que sabotam o cultivo da dinâmica da história do mundo, da história dos homens e da sua ética, que, conforme a nossa visão "sulista", deveriam ocupar o primeiro lugar na hierarquia de tudo quanto existe num povo, de tudo quanto existe numa etnia. Falamos de uma hierarquia que o Criador de todas as coisas não permitirá que seja subvertida nem pelo "nórdico". É ao menos o que nós do "sul" suspeitamos. Para as grandes organizações teutobrasileiras, o fato de 
terem traçado o seu caminho com precisão e decidido trilhá-lo, constitui-se na prova principal de sua viabilidade e de sua utilidade. Sobressaem aqui as importantes tarefas culturais, especialmente realizadas por algumas organizações sob a chancela da "grande comunidade teutobrasileria do trabalho 25 de julho".

As conclusões finais, nas quais, em última análise todas as outras têm origem, continuam sendo:

O nosso dever de permanecer decididamente no chão da nossa pátria. Esta base sólida nos garante a verdadeira segurança e liberdade de ação. O amor à terra natal deverá crescer em nossas casas como uma árvore em cuja sombra irá medrar o bem-estar dos nossos filhos.

Virá o dia em que já não existirá mais o teuto-brasileiro. Não nos devemos importar com isso. Contamos com muitos parceiros neste destino. Importa realizar o que o presente vivo exige de nós. Vivamos o momento presente. E o momento presente nos adverte vigorosa e seriamente: segura o que tens! $E$ pelo menos em silêncio todas as outras raças nos votam o seu reconhecimento, ainda mais quando notam que nos devotamos com determinação e orgulho ao que somos e que podemos continuar a ser em nossos filhos: da cepa alemã. (Volkstum und Volksgemeinschaft, p. 50-58).

\section{Reflexões sobre os Teuto-Argentinos}

Da mesma forma como no caso dos teuto-chilenos e dos teutobrasileiros, demos a palavra a intelectuais de nome, especialistas no assunto da identidade dos imigrantes alemães em fase de adaptação nos respectivos países, confiamos a tarefa de falar sobre os teutoagentinos para um conhecedor da realidade argentina neste particular. Está com a palavra Werner Hoffmann, com sua contribuição para a publicação: Die Deutsch-argentinischen Schulen - Beiträge zum Verständniss ihrer Geschichte und ihrer Gegenwart. Gedanken über ihre Zukunft (ditado por Harry Werner, em Bonn, 1973, p. 31-38).

Assim como acontece com tantas outras questões, discute-se e escreve-se sobre o tema teuto-argentinos sem a devida clareza em torno da abrangência e do sentido do conceito. Normalmente representa uma imprecisão quando se extrapola os limites do sentido de um conceito ou quando se conceitua mal o seu sentido. No nosso caso, as concepções divergem de tal forma, que não é de se admirar que se fale de coisas desencontradas.

Conforme as regras na composição de dois substantivos no alemão o segundo representa o substantivo principal e o primeiro o qualificativo. Desta maneira os teuto-argentinos não são alemães que, por algum tempo vivem na Argentina, mas de argentinos que ainda mantêm uma relação próxima com o que é alemão. 
No tempo do Terceiro Reich, acreditava-se que o sangue era o elemento determinante, e mesmo hoje ainda há pessoas que justificam a descendência de pais ou antepassados alemães, como qualificativo em nosso conceito composto. Contudo o estudo do contexto demonstrou que os descendentes de um povo em circunstâncias estranhas, se adaptam com o correr do tempo, física e psiquicamente, ao ambiente, mesmo que não se miscigenem com o povo da nova pátria, e que este processo tem o seu início já na primeira geração. A descendência não basta - é preciso esforço para permanecer o que se é. A designação teuto-argentino não é um carimbo que é impresso por ocasião do nascimento e permanece sem esmaecer até a morte, mas um conceito dinâmico, se assim podemos dizer. A pessoa torna-se teuto-argentina depois de viver por mais tempo como alemão na Argentina. Mesmo na terceira ou quarta geração é possível ser teuto-argentino, como é possível, quando se imigra muito jovem, já na primeira geração deixar de sê-lo e enculturar-se, como se costuma dizer por aqui. O pertencimento à comunidade teuto-argentina depende do fato de alguém preservar contato com a língua e a cultura alemã, ao nível de o alemão ainda ser a língua materna e que a pessoa se sinta em casa na cultura alemã. Não importa que os teuto-argentinos dominem perfeitamente o espanhol e mesmo em muitos casos o espanhol lhes seja mais familiar. [...]. Neste caso, um bom livro em alemão lhes dize muito mais do que um bom livro em espanhol, embora a leitura lhe exija esforço.

No momento em que entendemos como teuto-argentino aquela pessoa de descendência alemã, de cultura e língua alemã, não se pretende afirmar com isso que obrigatoriamente tenham que ter cidadania argentina. Um alemão que vive por mais tempo na Argentina, transformase em argentino, portando ou não um passaporte alemão. Ele desenvolve um sentimento de terra natal com o entorno em que vive e movimenta-se com maior desenvoltura na política e nos negócios do "país que o hospeda" do que nos negócios e na política alemã. Argentinos são seus amigos e quem sabe casou com uma argentina. Apesar de tudo, Ihe é possível preservar a língua e a cultura alemã.

[...].

Os teuto-argentinos têm consciência da ambigüidade (duplicidade, esquizofrenia). Eles preservam a língua não apenas por razões sentimentais, mas por motivos igualmente fortes oriundos de um sadio utilitarismo, pois sabem que a língua alemã os auxilia a avançar na vida. Os comerciantes alemães que em 1897 fundaram a Escola Belgrano, perseguiam pontos de vista práticos. No início emprestavam um valor todo especial ao ensino de qualidade de línguas estrangeiras modernas "utilizando o método da conversação", para o aproveitamento dos conhecimentos da língua alemã, correspondência comercial e introdução à contabilidade.

Entre as respostas dadas a um questionário do jornal Lasso, uma outra é digna de nota, porque representa um exemplo de que mesmo na quarta ou quinta geração é possível permanecer teuto-argentino e sentir- 
se inteiramente argentino, apesar de uma postura crítica em relação aos "velhos povos" e de sua política. Um escritor de 67 anos de idade fala da seguinte maneira sobre sua posição em relação à germanidade: "São quase cem anos desde que meus pais pisaram chão argentino. Ambos eram alemães do Reich. Eu da minha parte estou orgulhoso por ter nascido argentino e ao mesmo tempo ser de descendência alemã...".

Passei os primeiros anos da minha juventude no vasto campo argentino e com seis anos viajei para a Alemanha para freqüentar a escola. Devo a estes anos a consciência do dever que me acompanha na vida, mesmo que às vezes o "maldito" imperativo categórico do dever e do sentimento de culpa parecesse muito desconfortável. O domínio da língua alemã me foi um auxiliar precioso, porque me facultou a leitura das valiosas obras produzidas pelo espírito alemão, sem recorrer ao desvio das traduções em outras línguas. Quando meus netos, em cujas veias circula a mistura harmônica do sangue argentino antigo, o espanhol, o alemão, o francês e o inglês, me fazem perguntas sobre o ódio para eles incompreensível entre os povos europeus, respondo prontamente: Todo e qualquer ódio nacional precisa ser afundado no oceano quando os europeus migram para as plagas argentinas. Com a minha vida cumpro a missão de ser o intermediário para o melhor entendimento entre a maneira de ser alemã e argentina. Aqui a relação harmoniosa entre a adesão à "argentineidade" e a consciência do pertencimento ao círculo cultural alemão, deram um sentido e uma missão a uma vida: ser como escritor e tradutor um intermediário entre os dois mundos culturais.

[...].

$\mathrm{Na}$ medida em que se pode falar em teuto-argentino - já que a caracterização do indivíduo é difícil, muito mais complicado é falar em caracteres de um povo ou caracterizar grupos -, suas peculiaridades provêm da aproximação do alemão com a "argentineidade". O argentino acha o gringo alemão (imigrante) "quadrado" ("alemán quadrado", costuma-se dizer). Significa teimoso até o irracional, pouco acessível, lerdo. No relacionamento parece ao argentino como miudeiro, na atividade comercial falta-lhe o jogo de cintura. Leva tudo mortalmente a sério, e está firmemente convencido de suas qualidades (Vorzügen).

\section{Conclusões}

As considerações feitas acima permitem concluir que os imigrantes, independentemente da sua procedência étnica, passam obrigatoriamente por um processo de aculturação à sociedade nacional que os recebeu. Nessa fase de inserção, defrontam-se com uma situação de perplexidade existencial. Os valores da tradição, e principalmente a língua, vão sendo substituídos ou, no mínimo, ajustados aos valores e da língua da nova pátria. A segunda ou a terceira geração dos imigrantes começa a se dar conta de que já 
deixaram de ser o que foram e ainda não são o que seus filhos ou netos serão. Cada situação em particular dá origem a uma autoavaliação dos imigrantes. A situação criada com a imigração alemã no Chile, na Argentina e no Brasil, apresenta nuances peculiares à maneira como os teuto-chilenos, os teuto-argentinos e os teutobrasileiros se avaliaram neste período de transição, de modo especial nas primeiras décadas do século vinte.

\section{Referências}

Deutschbrasilianische Probleme. Sonderdruck einer Reihe im Deutschen Volksblatt, Porto Alegre, veröffentlichter Artikel von Dr. Franz Metzler (Porto Alegre: Companhia Metzler Ltda, 1935).

Die Argentinischen Schulen - Beiträge vom Verständnis ihrer Geschichte und ihrer Gegenwart. Gedanken über ihre Zukunft, herausgegeben von Harry Werner (Bonn, 1973).

Volkstum und Volksgemeinschaft - Was ist Volkstum - was Volksgemeinschaft. Das Ergebnis eines Preisauschreibens, veranstaltet und herausgegeben von Dr. Franz Metzler (Porto Alegre: Companhia Metzler Ltda., 1937). 